\title{
THE INTEGRATION OF SAP SOFTWARE IN LEARNING ACCOUNTING INFORMATION SYSTEMS TO FACE INDUSTRIAL REVOLUTION 4.0
}

\author{
Asri Diah Susanti ${ }^{1}$ \\ Pendidikan Akuntansi FKIP \\ Universitas Sebelas Maret \\ asridiahsusanti@staff.uns.ac.id*
}

\author{
Santoso Tri Hananto ${ }^{2}$ \\ Akuntansi FEB \\ Universitas Sebelas Maret \\ sthananto@yahoo.com
}

\author{
Sri Murni ${ }^{3}$ \\ Akuntansi FEB \\ Universitas Sebelas Maret \\ murnidj@gmail.com
}

\begin{abstract}
This study aims to improve student competence by integrating SAP in the SIA course in the industrial revolution 4.0. This research is a classroom action research. Data analysis methods used are quantitative and qualitative. Qualitative analysis is done by identifying the weaknesses and strengths of the application of actions and analyzing critical points. Quantitative analysis was performed by paired sample t-test to strengthen the results of the study. The results showed that there was an increase in student competence from moderate to high in cycle 1 . This result was also supported by the results of paired sample t-tests which showed that there was a difference in student competence before and after the integration of SAP in SIA courses.
\end{abstract}

Keywords: $\quad$ SAP software; accounting information system; industrial revolution 4.0

\section{ABSTRAK}

Penelitian ini bertujuan untuk meningkatkan kompetensi mahasiswa dengan mengintegrasikan SAP dalam MK SIA dalam menghadapi revolusi industri 4.0. Penelitian ini merupakan penelitian tindakan kelas. Metode analisis data yang digunakan adalah kuantitatif dan kualitatif. Analisis kualitatif dilakukan dengan mengidentifikasi kelemahan dan kelebihan penerapan tindakan serta menganalisis titik kritis. Analisis kuantitatif dilakukan dengan paired sample t-test untuk memperkuat hasil penelitian. Hasil penelitian menjukkan bahwa terdapat peningkatan kompetensi mahasiswa dari sedang ke tinggi pada siklus 1. Hasil ini juga didukung oleh hasil paired sample t-test yang menunjukan terdapat perbedaan kompetensi mahasiswa sebelum dan sesudah tindakan yaitu diintegrasikannya SAP dalam mata kuliah SIA.

Kata Kunci: SAP software; accounting information system; JEL Cassification: A220

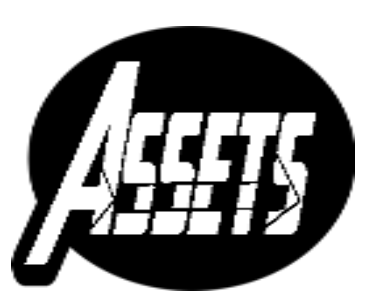

ASSETS

Jurnal Akuntansi dan Pendidikan

Vol. 9 No. 1

Hlmn. 72-82

Madiun, April 2020

p-ISSN: 2302-6251

e-ISSN: 2477-4995

Artikel masuk: 10 September 2019 Tanggal diterima: 26 April 2020 


\section{INTRODUCTION}

The Industrial Revolution 4.0 is a "trending topic" in the world of business and education. Many seminars bring this issue as the topic of the seminar. The industrial revolution I (IR-I) began in 1784 by empowering water and steam to run the production machines, the second IR began in 1870 when electricity was used to produce mass, the third IR began in 1969 when the power of electronics and IT were used for the production process, the fourth IR began when the technology has collaborated with integrated data called "big data". The industrial revolution 4.0 can be interpreted as rapid change characterized by new technologies and approaches that combine the physical, digital and biological world in ways that will fundamentally change humanity (Tjandrawinata, 2016).

Revolution 4.0 will have a direct effect on all aspects of life, including education. Bakrie (2018) explains that education 4.0 is an education characterized by the use of digital technology in the learning process or known as the cyber system. There are six competencies needed in the Education 4.0 era, namely critical thinking and problemsolving skills, communication and collaborative skills, creative thinking and innovation skills, information and communication technology literacy, contextual learning skills and information and media literacy. Stoner and Milner (2010) explains that there are two important competencies, they are classic and contemporary skills. Classical skills are related to analytical skills while contemporary emphasizes the use of IT. The importance of these two competencies causes the curriculum must be regularly reviewed to prepare the graduates. Education failed to prepare its graduates due to inadequate IT infrastructure and a lack of knowledge about new technologies (Rebele and St. Pierre, 2015). Education in this research is defined as higher education with the consideration that higher education is the initial gateway to enter the industrial world 4.0 .

A survey conducted in 2020 concerning the readiness of departments and accounting lecturers to respond to the digital industry revolution 4.0. obtained several findings. The first finding shows that the 4.0 industrial revolution influenced the accounting curriculum at the higher education level. The survey was conducted with all accounting lecturers throughout Indonesia in January 2019. The survey results showed $74 \%$ of respondents agreed that the 4.0 digital industry revolution affected accounting programs/curriculum in Indonesia. The next finding shows that the Accounting Information Systems (AIS) course is the subject most affected by the industrial revolution with a percentage of $90.6 \%$. The third fact shows that subjects that are closely related to the use of information technology are AIS with a percentage of 96.4\%.

AIS is a compulsory course that must be taken by accounting students at a bachelor degree. This course is taken in the third semester. It is very closely related to the use of information technology (IT). One of the achievements of this course is mastering techniques, principles, and procedural knowledge about the use of IT. Ardi (2013) mentions that IT progress has influenced the development of accounting information systems (AIS). IT progress has influenced AIS in terms of data processing, internal control of the company, and an increase in the amount and quality of financial information and reporting. Accountants who do not have sufficient knowledge about AIS will be displaced because they are unable to provide the services needed by clients or companies.

SAP itself is a software with high complexity. This software integrates one part with another part. SAP stands for system, application, and product. SAP is one of the 
Enterprise Resource Planning (ERP) software that is used by companies on a large scale. ERP is an information system that integrates the activities of different departments in a company such as production, payroll, purchasing sales, and financial reporting (Romney, Marshall B., 2015). The use of ERP makes all systems in a company easier to share data, and easier to communicate (real-time processing). The company will get benefit from offering integrated systems so the decision making will be more effective and efficient, the integration will be done globally so that it able to handle the cross-language problem, currency and cultural differences with integrated system make supply chain management run smoothly. The widely used ERP concept refers to SAP (Nazemi, Tarokh, and Djavanshir, 2012).

SAP is implemented by most national and multinational companies in Indonesia. Some of them are Astra International, Bank Mandiri, Bank BRI, Krakatau Steel, Indosat, and others. The use of an ERP-based system is evidence of changes in the accounting environment, related to accounting information systems (Tarigan, 2013). There is very little research and publication on ERP compared to the number of businesses that use this concept (Nazemi, Tarokh, and Djavanshir, 2012). Almost SAP research in Indonesia uses the case study method. Rahman (2018) found that application of SAP in PT. Surya Citra Television (SCTV) is successful but has problems in people who are resistant to system changes. SAP can integrate PT. Domusindo Perdana, but not all modules can be implemented because it is not under the company's business processes (Utami, Susilo and Riyadi, 2016). Similar to research at PT Domusindo, many studies have only raised one SAP module such as Qomariah (2015) examines the implementation of SAP human resource module has helped PT. KAI DAOP 8 Surabaya manages HR and overcomes previous system problems. SAP can overcome the problem of machine maintenance and production equipment with plant maintenance modules at PT. Len Industri (Pratama, Witjaksono, and Ambarsari, 2016).

According to the importance, that is why higher education organizations in accounting should make ERP discourse as part of its curriculum. Blount et al. (2016) explained that several universities in the world have integrated SAP into the curriculum including Louisiana State University, Grand Valley, Florida International University, Penn State, California State University, Northern Arizona University, South American University, Australian University. Furthermore, Blount et al. (2016) explained that there are several ways to integrate SAP with the curriculum, including being one of the learning materials in a particular course, taught through training by instructors out of class hours, or being a separate course in the curriculum. This result is also in line with Tarigan (2013) which states that there are several ways to introduce ERP in learning such as using demonstrations, laboratories, simulation games, and becoming a separate course or to be a student's final project. This research will answer two questions, whether the integration of SAP in AIS is effective to improve IT competencies of students facing the industrial revolution 4.0? and what is the most effective way of integrating SAP in the Accounting Learning curriculum?

\section{METHOD}

This research is a study using a qualitative approach by Classroom Action Research (CAR). AIS is a theoretical course that contains information systems to produce financial information in decision making. This course is taught with a tutorial or discussion that causes students to be less enthusiastic about attending the lectures. Lectures will be more interesting if the theories presented are also followed by practices that occur in the industrial world. It prompted researchers as AIS lecturers to conduct CAR. The action given in this study is the practice of using SAP in learning 
AIS. SAP is picked because most companies go public in Indonesia using this software to provide financial information. This method is appropriate because it suits the purpose, CAR is used to improve the quality of learning (Mulyasa, 2013). The CAR procedure is explained in Figure 1.

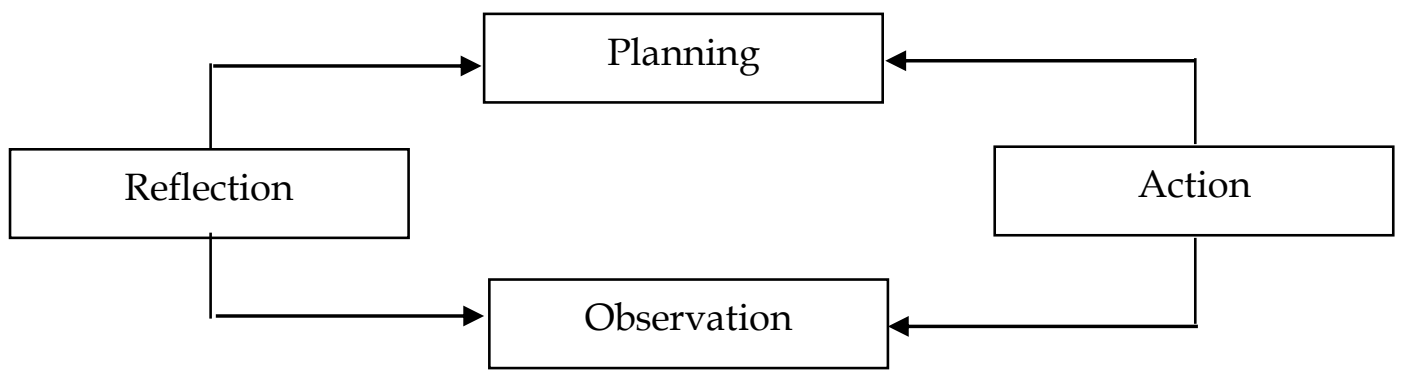

Figure 1. Classroom Action Research Cycle

The population in this study were undergraduate students of Accounting UNS who took the AIS course at even semester (February - July 2019) of 4 classes A, B, C, D. The sampling technique uses cluster random sampling considering the population in this study is a group. From the sampling results, classes $C$ and D were selected as samples with a total of 50 students. Data collection tool using a questionnaire. To test the questions the validity test was done using Pearson Product Moment, while the reliability test used Cronbach Alpha. Question items are declared valid and reliable if $r$ arithmetic > r table. Budiyono (2015) explains that this technique is appropriate for use in non-dichotomous instruments, for example in questionnaires or description tests.

Data analysis was carried out qualitatively using critical analysis techniques. This technique is used by identifying weaknesses and strengths during the process of applying actions. The analysis result will be served as material for developing plans to improve the implementation of actions in the next cycle. In addition to critical analysis, a comparative analysis is also presented and strengthened by statistical analysis. Statistical analysis in this study used paired sample t-tests. Different tests are used to evaluate certain treatments for the same sample at two different observation periods.

To see an increase in competence, researchers conducted observations in class and observed scores in a questionnaire. The indicator of success is adequate if the average score in study $\geq 5$ (Azwar, 2013). Azwar categorized the data into high, medium, and low criteria. In this study the research was successful if it qualified in the high category with the following calculations:

Height $=x \geq(\mu+1 \sigma)$

$=1 / 2($ maximum + minimum $)+1 / 6($ maximum-minimum $)$

$=1 / 2(7+1)+1 / 6(7-1)$

$=4+1=5$

\section{RESULT AND DISCUSSION}

Before the instrument is used for research, first it was tested for validity and reliability. The results of the validity and reliability test are shown in Table 1.

Table 1 shows that $r$-count Pearson Product Moment for all indicators is above $r-$ table ( $>$ 0.279). Cronbach Alpha also shows the r-count is above the r-table $(>0.6)$. These results show that all indicators asked are valid and reliable. After the questionnaire instrument proved to be feasible, the questionnaire was distributed to a 
sample of 50 students to give an initial description of students' knowledge about the industrial revolution $4.0 .100 \%$ of the 50 questionnaires are collected.

Table 1. Validity and Reliability Test Result

\begin{tabular}{llcc}
\hline No & \multicolumn{1}{c}{ Indicator } & $\begin{array}{c}\text { Pearson Product } \\
\text { Moment }\end{array}$ & $\begin{array}{c}\text { Cronbach } \\
\text { Alpha }\end{array}$ \\
\hline 1 & Critical thinking and problem-solving skills & 0,796 & 0,777 \\
2 & Communication and collaborative skills & 0,763 & 0,778 \\
3 & Creative thinking and innovation skills & 0,770 & 0,776 \\
4 & Information and communication & 0,863 & 0,762 \\
& technology literacy & & \\
5 & Contextual learning skill & 0,838 & 0,765 \\
6 & Information and media literacy. & 0,842 & 0,758 \\
\hline
\end{tabular}

The results of the questionnaire data indicate that $90 \%$ of students already knew about the industrial revolution 4.0. Students answered in an open questionnaire that the industrial revolution 4.0 was a change in all aspects of life because the development of information technology was marked by the Internet of Things (IoT), Artificial Intelligence (IA), and robotics technology. This result is supported by data on the competencies possessed by students to face RI 4.0 which is also quite high. A description of the accounting student competency questionnaire data for facing the industrial revolution 4.0 is shown in Table 2.

Table 2. Descriptive Analysis of Accounting Student Competencies

\begin{tabular}{llccc}
\hline No & \multicolumn{1}{c}{ Indicator } & Average & Maximum & Minimum \\
\hline 1 & Critical thinking and problem-solving skills & 4.92 & 7 & 3 \\
2 & Communication and collaborative skills & 5.00 & 7 & 3 \\
3 & Creative thinking and innovation skills & 4.96 & 7 & 3 \\
4 & Information and communication technology & 5.02 & 7 & 3 \\
& literacy & & & \\
5 & Contextual learning skill & 4.64 & 7 & 1 \\
6 & Information and media literacy. & 5.19 & 7 & 2 \\
& Average & 4.95 & & \\
\hline
\end{tabular}

Table 2 shows that the average competency of accounting students is moderate (4.59 from a scale of 7). Of the six indicators, the high score is indicator number 2, 4, and 6. It is consistent with the fact that students who take the AIS course are 3rdsemester students who are generation Z (born 1995-2010). Suganda (2018) explained that it is a generation that likes to socialize, express themselves, be active, be interested in visuals, and digital. The average student is proficient in operating communication and information media such as Facebook, Instagram, Line, Whatsapp, etc. Digital skills such as writing, drawing and even digital video to express themselves. The use of IT has not been maximally utilized in learning. This is indicated in indicators numbers 3 and 5 which are still in the medium category. Al-Htaybat, von Alberti-Alhtaybat and Alhatabat (2018) explains that learning for digital native must emphasize the ability of analysis and IT, so there must be action to improve these two points.

The use of IT in learning is contained in the Indonesian National Qualification Framework (KKNI) Bachelor Degree of Accounting Program on Special Skills (KK10). KK10 states that students can independently operate and utilize software in the 
framework of preparing financial reports, budgets, tax administration, auditing, and research. KK10 is also one of the learning goals on the AIS course. In business schools (part of Canadian universities) that have been accredited by AACSB the use of accounting software improves the accounting competence of a thousand students as research samples (Boulianne, 2014). This research focuses on software operations in the context of preparing financial statements.

In this study, the AIS course is chosen and supported by the results of an open questionnaire. Students answer the most influential subjects with the existence of RI 4.0 is the Accounting Information System (AIS) of 79\% which is shown in Figure 2.

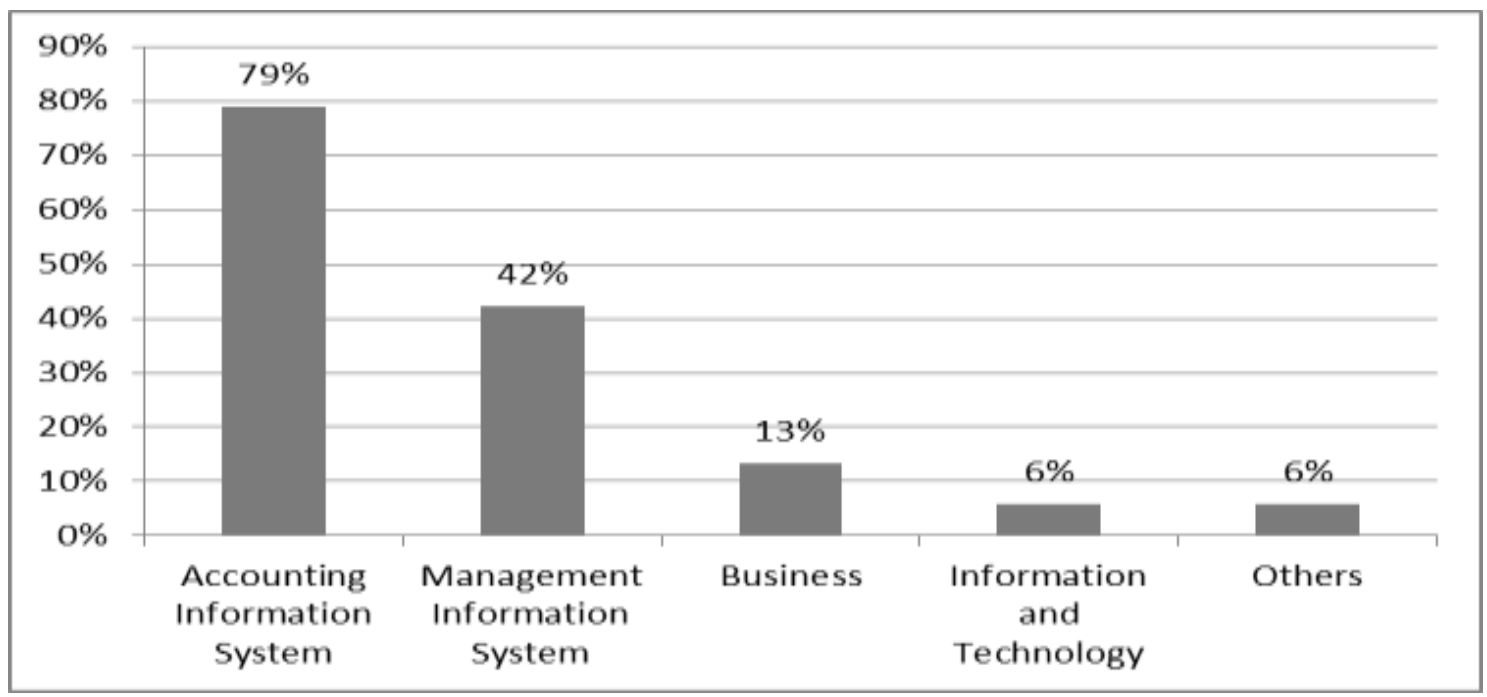

Figure 2. Influential Subjects of IR 4.0

Students understand the importance of AIS to face IR 4.0, but only $35 \%$ of students answer additional material that needs to be included in the AIS, the remaining $65 \%$ answer not knowing. Additional material in question is the use of information technology with the use of the software. SAP software that will be taught is SAP fundamental. The features in SAP are fundamentally precisely integrated with the AIS course.

After getting the initial plan, the action starts with planning. AIS course staff and assistants coordinate to make Semester Learning Plans (RPS). RPS is prepared by inserting SAP practices in the AIS course. AIS course in UNS Accounting Bachelor Study Program has 16 meetings of 3 SKS. Each SKS consists of 50 minutes face to face, 60 minutes structured assignments, and 60 minutes of independent study. So each meeting will consist of 150 minutes face to face, 150 minutes structured assignments, and 180 minutes of independent study. The lecturer takes the portion of 150 minutes for face to face, while the assistant takes the 150 minutes for structured assignment. Lecturers will teach AIS theory then SAP will be taught by course assistants because of the large amount of study material.

Actions will begin at the 2nd meeting. It was considering that at the first meeting, the study material will be the introduction of accounting information systems (AIS). The action is planned for 8 sessions. In session 1, the second meeting the lecturer explained the material Enterprise Resource Planning (ERP) and ERP implementation in SAP. Preliminary data retrieval is also carried out in this session so that students have got a big picture of AIS and SAP. The next stage SAP is demonstrated by an assistant at out of the class hour for 7 sessions, which is sessions $2-8$. The material that will be 
taught by the assistant is the introduction in session 1 , navigation in session 2 , the system-wide concept in session 3, logistics in session 4, accounting in session 5, human capital management in session 6, and SAP technology in session 7. The material taught by the assistant is adjusted to the lecturer's meeting in class.

The next stage of CAR is implementation. Session 1 starts at the second meeting according to the plan. In session 1 the lecturer and assistant go together in class. The lecturer explained about ERP then the assistant explained the introduction of SAP and navigation. In this session, it is also explained about the methods that will be used in class and assistance and what material will be given so lecturers and assistants need to get into the class together. Session 2 starts at the 7th meeting on the expenditure cycle under the developed RPS. The next meeting session 3-7 discussed revenue cycle, production cycle, human resources and payroll, general ledger and reporting system. The material taught by the lecturer is then followed by the activity of using SAP outside of class hours by an assistant. The material is given starts from the system-wide concept in session 2. In session 3 the assistant provides material on the procurement chapter logistics. Logistics material cannot be taught during one session, given the relatively large amount of material which includes procurement, sales order management, and production. This material will take 3 sessions, session 3 to session 5 .

In session 5 of assistance activities, the lecturer monitors and observes by participating in assistance activities. In addition to attending the observation class, the lecturer also conducts interviews with students. The results of observations in class average students can use SAP. SAP practice in assistance classes has been supported by adequate modules and facilities that make it easy for students to practice SAP using. The assistant goes to the student if there are difficulties and steps are left behind. The interview results of several students also showed that they were happy because they could directly practice in the laboratory with a more relaxed atmosphere than learning in the classroom. The fact that is found during observation and interviews is that students have not been able to link SAP's practices with the material taught in class about AIS material such as System Development Life Cycle (SDLC). In assistance classes, assistants tend to only explain the steps and tend to just "click" without explaining the relationship with the AIS. This is reinforced by when there was a quiz that linked AIS with SAP, almost $80 \%$ of students could not answer the question correctly.

Based on the findings of the observations and interviews so a reflection is conducted. The lecturer analyzes the cause of the problem. The first thing to do is discuss it with the assistant. The assistant stated the difficulty in adjusting the lecturer material because of the depth and breadth of the different materials between AIS and SAP. In SAP the expenditure cycle, the income cycle, and the production cycle are discussed in one module like logistics, while in the third AIS the material is discussed in a different chapter. Based on the discussion, the lecturer changed the learning design for sessions 6 through session 8 . In the face-to-face session, the last 50 minutes were used by the lecturer to explain SAP so that no information will be lost between the AIS and SAP material. The SAP practice in detail will still be continued by the assistant to fill in the structured assignment time because of the limited face-to-face time. The process lasted for 2 sessions with material on the accounting and reporting cycle and the human resource and payroll cycle.

The last session of assistance is used to conduct SAP certification exams. Test results show $100 \%$ of students pass the certification. Students are declared to have passed the certification if the test scores are more than 70. A list of students and student scores can be seen in appendix 3. These results indicate that students have 
mastered SAP and are expected to increase student competency. Increased competence is also felt by students during student internships. Students feel helped by the mastery of SAP at the time of the internship (appendix 5). Internships are compulsory courses that accounting students must take as an introduction to the world of work. If SAP is very supportive during the apprenticeship process, SAP is expected to be equipped to compete in the world of work in the era of RI 4.0

To strengthen research results, a questionnaire was distributed to measure the increase in accounting student competencies in dealing with RI 4.0. Competency improvement is not measured using tests because the comparison is not balanced (apple to apple). At the time of the pretest, SAP has not been given while the post-test has been given. The results of this questionnaire indicate that there is an increase in the ability indicators of students shown in Table 3. Table 3 also shows that the average post-test indicator is 5.23 which means that the research has been successful in cycle 1 $(5.23>5)$.

Table 3. Comparison of Accounting Student Competencies

\begin{tabular}{llccc}
\hline No & \multicolumn{1}{c}{ Indicator } & $\begin{array}{c}\text { Pre- } \\
\text { action }\end{array}$ & Cycle- I & Increase \\
\hline 1 & Critical thinking and problem-solving skills & 4.92 & 5.32 & $8 \%$ \\
2 & Communication and collaborative skills & 5.00 & 5.18 & $4 \%$ \\
3 & Creative thinking and innovation skills & 4.96 & 5.22 & $5 \%$ \\
4 & Information and communication technology & 5.02 & 5.10 & $2 \%$ \\
& literacy & & & \\
5 & Contextual learning skill & 4.64 & 5.24 & $13 \%$ \\
6 & Information and media literacy. & 5.19 & 5.32 & $\mathbf{2} \%$ \\
& Total & $\mathbf{4 . 9 5}$ & $\mathbf{5 . 2 3}$ & $\mathbf{6 \%}$ \\
\hline
\end{tabular}

Table 3 shows that student competencies have increased from moderate (4.95) to high (5.23). The average increase is 6\% where most competencies have increased competency number 5 is the use of technology in learning by $13 \%$. The paired sample $t-$ test results also support the results of the study which indicated a significance value of 0.006 above 0.05 . It means that there are significant differences in the ability of students before and after SAP integration in the AIS course. The results of this questionnaire are the opinions of students who are expected to be able to explain their experience and how they feel. To strengthen this result it would be better if it was added with an observation sheet.

Table 4. Additional Materials in The AIS Course

\begin{tabular}{ll}
\hline No & \multicolumn{1}{c}{ AIS course material } \\
\hline 1 & Practicing the systems making \\
2 & Coding \\
3 & Computer programs making \\
4 & Software Development \\
5 & Checking the AIS of companies that use e-money or fintech \\
\hline
\end{tabular}

The research questionnaire consisted of closed and open statements. The closing statement is used to measure student competency using 6 indicators. While the questions are open to further explore student knowledge about IR 4.0. One statement that reinforces this research is related to the statement of learning material needed to 
deal with IR 4.0. The post-test results of the statement indicate that the need for software in the pre-test was answered by the use of SAP. It is indicated by no response to the addition of software material in the AIS course. Some additional material that needs to be integrated with the AIS course is shown from the post-test results in table 4.

Table 4 shows that according to students, the material needs to be added in the AIS course especially material related to simple programming. It has not yet appeared in the AIS course's RPS. The addition of this material can be done through training or visiting lecturers in the field of Information and Computer Technology (ICT) considering the burden of the AIS course's SKS is only have 3 SKS with a lot of material.

The explanation above shows that the integration of SAP with the AIS course can improve accounting student competencies in dealing with IR 4.0. These findings are logical because the characteristic of IR 4.0 is the use of IT in all fields including education. SAP is one of the accounting software that uses in advanced technology with the use of the internet on an ERP basis. AIS course is the most appropriate course to be integrated with SAP where one of the learning outcomes of the course is the mastery of the software. There is an incision between SAP, AIS, and IR 4.0, which is the use of IT as shown in Figure 3.

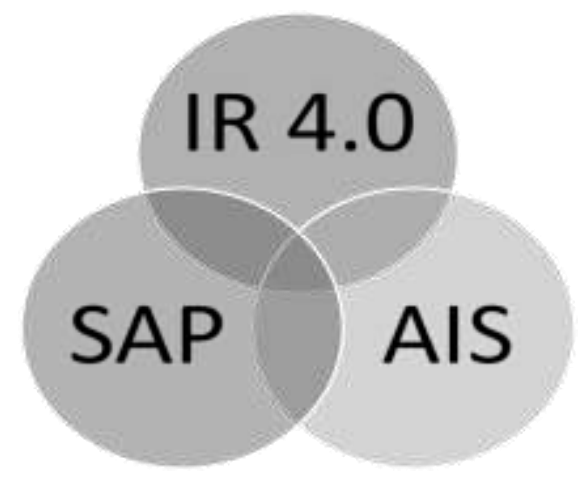

Figure 3. Incision between SAP, AIS, and IR 4.0

Figure 3 also shows that IT mastery is very important in dealing with IR 4.0, so it must be seen in the curriculum. Under the KKNI of Accounting in Bachelor Degree, AIS is the most appropriate course to incorporate the elements of IT and SAP software because it is one of the right ways to improve IT capabilities in accounting learning. ERP now has also been developed with cloud computing and user friendly-Appendix 6 (Sheng, YauLiang and YuHsu, 2015). This research is related to the results of Blount et al. (2016) which states that SAP is important to be included in the higher education accounting curriculum.

\section{CONCLUSION}

The results of the study concluded that the integration of SAP in the AIS course increased the ability of students to face IR 4.0. The weakness of this study in terms of measurement. Competency measurement is only based on a questionnaire so that the level of subjectivity is so high. In conducting the research, the method of reflection from the results of the reflection is done, but this study cannot compare the most appropriate method to integrate SAP into the AIS.

Suggestions for further research are to make the best experimental method for integrating SAP in the AIS course relate to the weaknesses found in this study. The 
method can be SAP taught by the lecturer directly so that the relationship between AIS and SAP can be understood by students or become a separate subject in the curriculum, or still taught by an assistant but monitored by the lecturer. To reduce subjectivity, it is better to use additional measuring instruments in the form of observation sheets and learning outcomes tests.

Classroom action research is mostly carried out in enclosed study programs or educational areas, not in pure science. In addition to delivering material, the lecturer is also responsible for class management and student competency achievements. Lecturers should, including lecturers of pure science, do CAR to improve the quality of their learning. This research is expected to give the color of pure science lecturers research in conducting research. For students, this research is expected to be used as a trigger to upgrade their abilities, especially IT issues to compete in IR 4.0.

\section{REFERENCES}

Al-Htaybat, K., von Alberti-Alhtaybat, L. and Alhatabat, Z. (2018) 'Educating digital natives for the future: accounting educators' evaluation of the accounting curriculum', Accounting Education. Taylor \& Francis, 27(4), pp. 333-357. doi: 10.1080/09639284.2018.1437758.

Ardi, B. K. (2013) 'Stie Dharmaputra Semarang Dharma', (38), pp. 1-12.

Ayu Laely Qomariah (2015) 'Penerapan System Application And Product (SAP) Pada Administrasi Kepegawaian Di PT KAI (Persero) DAOP 8 Surabaya', Jurnal Penerapan System Application and Product, pp. 4-5.

Azwar, S. (2013) Metode Penelitian. Yogyakarta: Pustaka Pelajar.

Bakrie (2018) Menjadi Guru Era Pendidikan 4.0. Available at: http://aceh.tribunnews.com/2018/11/27/menjadi-guru-era-pendidikan40?page $=2$.

Blount, Y. et al. (2016) '6 CrossRef citations to date 0 Altmetric Case Study Integrating enterprise resource planning (SAP) in the accounting curriculum: a systematic literature review and case study', Accounting Education, 25(2), pp. 185-202.

Boulianne, E. (2014) 'Impact of accounting software utilization on students' knowledge acquisition: An important change in accounting education', Journal of Accounting and Organizational Change, 10(1), pp. 22-48. doi: 10.1108/JAOC-12-2011-0064.

Mulyasa (2013) Praktik Penelitian Tindakan Kelas. Bandung: Rosdakarya.

Nazemi, E., Tarokh, M. J. and Djavanshir, G. R. (2012) 'ERP: A literature survey', International Journal of Advanced Manufacturing Technology, 61(9-12), pp. 999-1018. doi: 10.1007/s00170-011-3756-x.

Pratama, D., Witjaksono, W. and Ambarsari, N. (2016) 'Penerapan Sistem Informasi Berbasis Enterprise Resource Planning Menggunakan SAP Modul Plant Maintenance di PT. Len Industri', Sisfo, 06(01), pp. 37-50. doi: 10.24089/j.sisfo.2016.09.003.

Rahman, F. (2018) 'Evaluasi Penerapan Enterprise Resources Planning (Erp) Terhadap Penyajian Laporan Keuangan (Studi Kasus Di Pt. Surya Citra Televisi)', KREATIF : Jurnal Ilmiah Prodi Manajemen Universitas Pamulang, 6(3), p. 109. doi: 10.32493/jk.v6i3.y2018.p109-126.

Rebele, J. E. and St. Pierre, E. K. (2015) 'Stagnation in accounting education research', Journal of Accounting Education. Elsevier Ltd, 33(2), pp. 128-137. doi: 10.1016/j.jaccedu.2015.04.003.

Romney, Marshall B., P. J. S. (2015) Accounting Information Systems. 13th edn. Prentice Hall: Pearson Education, Inc. 
Sheng, C., YauLiang, C. and YuHsu, H. (2015) 'A cloud computing platform for ERP applications', Applied Soft Computing, 27(February), pp. 127-136.

Stoner, G. and Milner, M. (2010) 'Embedding generic employability skills in an accounting degree: Development and impediments', Accounting Education, 19(12), pp. 123-138. doi: 10.1080/09639280902888229.

Suganda, T. (2018) Pengelolaan Pembelajaran Generasi Z. doi: 10.13140/RG.2.2.23700.60800.

Tarigan, J. (no date) 'Enterprise Resource Planning ( Erp ): Dampak Dalam Pendidikan , Profesi Akuntan Dan Auditor'.

Tjandrawinata, R. (2016) 'Industri 4.0: revolusi industri abad ini dan pengaruhnya pada bidang kesehatan dan bioteknologi', (February). doi: 10.5281/zenodo.49404.

Utami, S., Susilo, H. and Riyadi, R. (2016) 'ANALISIS PENERAPAN ENTERPRISE RESOURCE PLANNING (ERP) (Studi pada PT Domusindo Perdana)', Jurnal Administrasi Bisnis S1 Universitas Brawijaya, 33(1), pp. 165-170. 